\title{
ПАТОМОРФОЛОГІЧНІ ЗМІНИ В ОРГАНІЗМІ ТЕЛЯТ ПРИ ПРОТОЗООЗАХ, ЗАХОДИ ПРОФІЛАКТИКИ
}

\author{
Коваленко Лідія Михайлівна \\ кандидат ветеринарних, доцент \\ Сумський національний аграрний університет (м. Суми, Україна) \\ ORCID: 0000-0002-4350-2284 \\ lidiia.kovalenko@snau.edu.ua \\ Коваленко Олександр Іванович \\ кандидат ветеринарних, доцент \\ Сумська регіональна лабораторія Державної Служби України \\ з питань безпечності харчових продуктів та захисту споживачів (м. Суми, Україна) \\ Vetlabsumy@ukr.net
}

За результатами ряду досліджень встановлений широкий спектр розповсюдженості протозоозів серед тварин, це питання розкривається в даній статті. Територіальне розташування Сумської області на Півночі України має особливі природно-кліматичні зміни, а це є одним із фракторів виникнення та розповсюдженості криптоспоридіозу серед тварин. Криптоспоридіоз телят має широке розповсюдження в господарствах Сумської та Чернігівської областях. Екстенсивність інвазії у різних районах коливається від 12,4 \% до 81,4 \% та в середньому складає 41,23 \% від обстеженого поголів'я. В різних територіально кліматичних зонах розташування господарств при обстеженні був майже однаковий рівень ураженості телят ві 39,3 \% до 81,4%. При обстежені хворих тварин був виявлений збудник Cryptosporidium parvus.

Термін ураженості та розвиток інвазії у новонароджених телят залежить прямо-пропорційно від їх утримання та сезонності. Починаючи вже з четвертої доби від народження реєструється виділення ооцист. Максимальна кількість спостерігається на сьому добу і показник складав 50,8 + 0,47 \% в зимовий період та від 29,6 + 0,25 \% до 42,8 + 0,31 \% в літню пору року.При ураженості криптоспоридіями у телят спостерігається два піка екстенсивності інвазії. Перший реєструється на п'ятий день з початку виділення збудника. На сьому добу встановлюється друга хвиля виділення ооцист. Тривалість виділення ооцист Cryptosporidium у телят складає до 21 доби від народження.

Ветеринарно-санітарні умови утримання тварин відіграють значну роль у розповсюдженні збудника криптоспоридіозу серед сприйнятливого поголів'я. Накопичення ооцист у зовнішньому середовищі, обумовлює постійна його циркуляція у тваринницьких приміщеннях по утриманню новонароджених телят.

При гематологічному дослідженні встановлена екстенс-ефективність препаратів кокцидіостатиків при комплексному застосуванні. При їх використанні в крові тварин, які підлягали лікуванню, збільшується кількість гемоглобіну, еритроцитів. Рівень лейкоцитів та показники лейкограми відповідають фрізіологічній нормі в процесі видужання.

При лабораторній діагностиці використовували модифрікований метод сегментації в розчині поверхневоактивних речовин. В якості засобів, які гальмують розвиток збудника, використовували комплексно препарат вітчизняного виробництва Бравітакокцид в дозі 1,5 г/10 кг маси тіла з вітаміном $B_{1}$ та поєднували з препаратами, які стабілізують обмін речовин в організмі тварин. Особливу увагу приділяли підготовиі приміщень з утримання новонароджених телят, з попереднім дослідженням в лабораторних умовах, змивів з стін, станків, предметів побуту, на забрудненість ооцистами збудника С. Parvuт та інших представників інвазійних збудників.

Ключові слова: ооцисти, біохімічний аналіз, гематологічні дослідження, кров, фецес, товстий відділ кишковика, слизова оболонка, бравітакокцид, бровасептол.

DOI: https://doi.org/10.32845/bsnau.vet.2020.4.2

Вступ. Із числа регіональних об'єктів Північної частини України важливе місце в сільському господарстві займає скотарство. Гастроентерити телят на ранньому етапі стають причиною неблагополуччя господарства. Це визначається цілим комплексом етіологічних факторів. Збудники захворювання та інфіковані тварини сприяють забрудненості навколишнього середовища. Вони зумовлюють зниженню імунного рівню молодняка великої рогатої худоби. На теперішній час ще недостатньо вивченні фактори розвитку хвороби, що має ускладнену діагностику на криптоспоридіоз. Збудниками у телям встановлені Cryptosporidium parvum i C.muris, відносяться до типу Sporozoa, класу Coccidida, родини Cryptosporidiidae. У збудників криптоспоридіозу, яскравої специфічності не виявлено, по відношенню до хазяїна, тому це зооантропозоонозне захворювання залишаеться проблемой як для ветеринарної, так і гуманної

медицини (Grebenev A.L., Myagkova L.P., 2006). Різноманітність дії простіших на організм господаря утруднює достовірність діагностичних даних. Лабораторні методи діагностики не мають високу чутливість до збудників, це пов'язано з їх морфологічними особливостями. Сучасна наукова діяльність спрямовується на розробку ефективних заходів боротьби з криптоспоридіозом. Збудники розвиваються за схеою гомоксенного життєвого циклу кокцидій, тобто повний їх розвиток проходить в організмі одного хозяїна. Завершується розвиток паразиту виділенням з фекаліями ооцист, які мають стійкість до дії несприйнятливих факторів. Ооцисти зберігаються у зовнішньому середовищі більш тривалий час і уражують нових хазяїв. За результатами дослідницької роботи в цьому напрямку, недостатньо розроблені засоби, які сприяють блокуванню розвиток збудників як в організмі хазяїна, так і в навколишньому середовищі (Zhurenko V.V., 
Soroka N.M., Zhurenko O.V., 2016).

Госпдоговірна тематика «Заходи боротьби та профілактики захворювань тварин» дозволила нам провести моніторинг розповсюдженості криптоспоридіозу тварин в господарствах Північної частини України.

Аналіз останніх досліджень і публікацій. Баготочисельні наукові дослідженя свідчать, що протозоози мають широке розповсюдження в господарствах серед молодняка тварин раннього віку, у різних територіально - кліматичних зонах. Особлива увага надається етіологічним факторам. За статистичними даними, важливе значення набувають метеорологічні умови, які сприяють поширенню збудників у зовнішньому середовищі. Починаючи з початку дев'яностих років науковцями розкриваються питання, щодо виявлення простіших роду Cryptosporidium у телят, в якості перебігу захворюваності в тяжкій формі, з ураженням органів травлення (Gnanasoorian S., 1998; Krasnova O.P., Larionov C.B., Rozovenko M.V., 2002). Основні симптоми криптоспоридіозу $€$ явища діареї, з домішками крові та різке виснаження організму. Новонароджені телята значно сприйнятливі до кокцидій так, як доведено, що в молозиві не виявлені імуноглобуліни проти збудників роду Cryptosporidium. За результатами наукових робіт встановлено, що криптоспоридіоз реєструється в будь яку пору року. Максимальний прояв визначається на початку весняного періоду, у неонатальних телят розвивається імунодефіцит (Anusz K.Z., Mason P.H., Riggs M.W., Perryman L.E., 2002).

Широкий спектр діяльності лікарів ветеринарної медицини в господарствах Сумської та прилеглих територій Чернігівської області спрямований на досконале вивчення епізоотології криптоспоридіозу тварин. На теперішній час ведеться пошук нових ветеринарних препаратів, які при їх застосуванні мали б 100\% еерективність при протозоозах. Фермерські господарства по вирощуванню великої рогатої худоби Сумщини, яка розташована на Півночі України, щорічно мають збитки від загибелі молодняка раннього віку. Цей показник складає від 14,2 \% до 21,7\% від новонароджених.

Аналізуючи дану проблему стає необхідним повертатися до цього питання. Вияснити ступінь розповсюдженості криптоспоридіозу телят, етіологічні фрактори, які спонукають до ураженості тварин. Розкрити патогенез і рівень терапії та профілактики цього захворювання в типових господарствах.

Мета роботи полягала у проведенні статистичного аналізу відносно до епізоотології протозоозів тварин, з урахуванням територіального розташування господарств. Вивчити основні питання клінічної картини, механізму розвитку захворювання. Проаналізувати патологоанатомічну картину загиблих тварин. На підставі досліджень взяти за основу: гематологічні, біохімічні методи для диференційної діагностики. Провести симптоматичну і патогенетичну терапію телят при криптспоридіозі з використанням кокцідіостатиків.

Матеріали і методи досліджень. Досліди проводили в умовах фермерських господарств СТОВ «Ранок», ТОВ «Беєво», ПСП «Камишанське» Сумської та Чернігівської областей. Статистичний матеріал, відносно до епізоотології та етіології інфекційних хвороб був отриманий в протиепізоотичному відділі головного управління Держпродспоживслужби у межуючих областях. Окремі етапи досліджень проводили у відділах імунологічному, бактеріологічному та патоморфологічному Сумської регіональної лабораторії Державної Служби України з питань безпечності харчових продуктів та захисту споживачів та ДНДІЛДВСЕ.

Вивчення епізоотології криптоспоридіоза телят проводили в господарствах 3 урахуванням природнокліматичного зонування, технології утримання і породи тварин. При вивченні ареалу розповсюдження захворювання діагноз на криптоспоридіоз встановлювали комплексно, з урахуванням епізоотологічної ситуації в господарстві, клінічного прояву захворювання і результатів лабораторних досліджень, проведених у відповідності до «Методичних вказівок: «Криптоспоридіоз телят, екологія, епізоотологія, клініка, діагностика, лікування, профрілактика», «Методичних рекомендацій по виділенню та ідентифікації умовно-патогенних збудників при кишечних захворюваннях молодняка сільськогосподарських тварин». Обстежили по 20-25 телят, підібраних у господарствах за принципом аналогів, які мали яскраву картину діареї.

Для бактеріологічного дослідження від вимушено забитих і загиблих телят відбирали відрізки товстого і тонкого кишковика, паренхіматозні органи, мезентеріальні лімфовузли, трубчату кістку. Від живих телят фекалії брали індивідуально із прямої кишки, а від загиблих з тонкого відділу кишечника. Проби фецес розташовували в стерильний посуд з притертими кришками. Їх пронумеровували і доставляли в лабораторію. Інтенсивність інвазії тварин установлювали за встановленою шкалою (Клесова Д.М, 1996). В бактеріологічно-паразитологічному відділі кожну доставлену пробу фекалій досліджували за допомогою наступних методів: виготовлення нативного мазка за загальноприйнятою методикою; центрифугування проб фекалій в дистильованій воді; центрифугування в насиченому розчині хлориду натру (Бейер Т.В.,1987), модифікований метод сегментації матеріалу 3 поверхносно-активною речовиною (Dahno I.S., Berezovsky A.V., Galat V.F., 2001). Виготовляли нативний препарат. Для цього на обезжирене предметне скло наносили краплю проби фекалій. У співвідношенні 1:1 добавляли краплю суміші гліцерину з водою. Розмішуючи прикривали покривним скельцем. Готові мазки проглядали під імерсійною системою світлового мікроскопу МБІ-3 при збільшенні 90х10. При великій забрудненості препарату розчин гліцерину замінювали краплею метиленової сині.

В наші дослідження був включений метод центрифужно-фрлотаційний із застосуванням розчину у модифікації (Beyer T.V., Sidorenko N.V., Grigoriev M.V., 1995). Видовий склад криптоспоридій визначали за виділеними ооцистами за «Класифікатором паразитичних простіших» (Casemore D.P., 1998) та за методиками відповідно «Довідника виділення інтенсивності ооцист» (Anusz K.Z., Mason P.H., Riggs M.W., Perryman L.E., 2002). Чисельність виділення ооцист 3 розрахунку 1 г фекалій встановлювали ступінь інвазованості тварин у хрестах: «+» це слабка від 1до 5 ооцист у полі зору що дорівнює від 5000 до 50000 ОД/г фекалій; «++» середня від 6 до 10 ооцист це 55000-1000000 ОД/г фекалій; «+++» сильна, більше 10 ооцист має відповідність більше 1000000 ОД/г фекалій. Дані результати встановлюються при мікроскопії у збільшенні в 600 разів.

Дослідження патологічного матеріалу проводили у Сумській регіональній лабораторії Державної Служби України з питань безпечності харчових продуктів та захисту спо- 
живачів на виключення вірусних, бактеріальних інфекцій: колібактеріозу, сальманельозу, рота-, парво- і аденовірусів. При встановленні терапевтичної ефективності застосованих препаратів відбирали зразки крові тварин для встановлення змін морфологічних показників. Гематологічні дослідження на криптоспоридіоз базувалися на наступних методиках: швидкість осадження еритроцитів за методом Панчинкова; визначені кількості гемоглобіну за Салі; підрахунок кількості еритроцитів і лейкоцитів та лейкоцитарного профілю. Наші дослідження, також, були направлені на біохімічні дослідження крові, за загально прийнятими методиками (Hall M.C., 2001).

Весь цифровий матеріал був опрацьований біометрично. Лікувальну ефективність кокцидіозних препаратів в свій час визначали Anusz K.Z., Mason P.H., Riggs M.W., Perryman L.E. (2002), Grebenev A.L., Myagkova L.P. (2006), результативність встановлена на наявність збудників асоційованої форми інфекційних хвороб телят.

\section{Результати досліджень.}

Аналізуючи матеріал відносно розповсюдженню захворювання поголів'я на паразитарну інвазію, встановлено, що природно-кліматичні умови впливають на розвиток збудників хвороб. Помірно тепле літо, атмосферні опади та відносно помірно м'яка зима сприяє циркуляції та інвазійному початку у зовнішньому середовищі. Особливістю Сум-

щини є велике перетинання річок, заливних луків, які стають пасовищними угіддями для сільськогосподарських тварин та, також, для забезпечення кормовою базою господарств. Вологість і висока температура зовнішнього середовища $є$ неод'ємним фактором поширенню протозойних хвороб, особливо гострому їх перебігу (Vasilieva V.A., Nebaykina L.A.,1998; Beyer T.V., Antikova L.P., Gerbina G.I., 2010). Широке розповсюдження кишкових паразитів серед тварин і людини сприяють інтенсивному обсіменінню об'єктів навколишнього середовища інвазійним матеріалом, що в свою чергу утворюють умови для інтенсивного перезараження (Grebenev A.L., Myagkova L.P., 2006).

Епізоотологічним обстеженням господарств трьох районів області, протягом двох років, було виявлено захворюваність телят на криптоспорідіоз. При дослідженнях ми проаналізували статистику захворювання поголів'я у різну пору року і зональністю розташування господарства. За результатами наших досліджень екстенсивність інвазії (ЕI) була різною. В господарстві ПСП «Комишанське» ураженість тварин в літньо-осінній період складала 72,6\%, зимововесняний до 81,9\%. Поголів'я тварин в ТОВ «Беєве» мало інвазованість від 12,4 до 19,6 \% відповідно, а телята, які належали СТОВ « Ранок» були інфіковані на 38,7 - 39,3 \%. Інтенсивність виділення ооцист с фекаліями телят встановлювалась від значної до середньої.

Показники ступеня інвазії у тварин в обстежених господарствах області відображені в таблиці 1.

Ураженість телят криптоспоридіями в господарствах Сумської області

Таблиця 1. в зимово-весняну пору року

\begin{tabular}{|c|c|c|c|c|c|c|}
\hline \multicolumn{7}{|c|}{ Зимово-весняна пора року } \\
\hline \multirow{2}{*}{ Назва господарства } & \multirow{2}{*}{$\begin{array}{c}\text { Обстежено, } \\
\text { гол }\end{array}$} & \multirow{2}{*}{$\begin{array}{c}\text { Інвазовано, } \\
\text { гол }\end{array}$} & \multirow{2}{*}{$\begin{array}{l}\mathrm{El}, \\
\%\end{array}$} & \multicolumn{3}{|c|}{ Інтенсивність виділення ооцист, \% } \\
\hline & & & & Мін. & Серед. & Макс \\
\hline ПСП «Комишанське» & 127 & 104 & 81,9 & $5 / 2,7$ & $87 / 46,5$ & $95 / 50,8$ \\
\hline ТОВ «Беєве» & 46 & 9 & 19,6 & $2 / 1,3$ & $38 / 21,7$ & $41 / 32,1$ \\
\hline СТОВ «Ранок» & 70 & 27 & 39,3 & $4 / 2,2$ & $43 / 35,6$ & $65 / 41,9$ \\
\hline Загальний показник & 243 & 140 & 46,77 & $11 / 2,1$ & $168 / 34,6$ & $201 / 41,6$ \\
\hline
\end{tabular}

Як видно з представленої таблиці більш висока екстенсивність інвазії та інтенсивність, за виділенням ооцист, визначали в зимно-весняний період. Цей показник мав від-

хилення на 5,21 \% відповідно до літньо-осінньої пори року (табл.2).

Таблиця 2.

Ураженість телят криптоспоридіями в господарствах Сумської області в літньо-осінню пору року

\begin{tabular}{|c|c|c|c|c|c|c|}
\hline \multirow{3}{*}{ Назва господарства } & \multicolumn{6}{|c|}{ Літньо-осіння пора року } \\
\hline & \multirow{2}{*}{$\begin{array}{c}\text { Обстежено, } \\
\text { гол }\end{array}$} & \multirow{2}{*}{$\begin{array}{c}\text { Інвазовано, } \\
\text { гол }\end{array}$} & \multirow{2}{*}{$\begin{array}{l}\text { El, } \\
\%\end{array}$} & \multicolumn{3}{|c|}{ Інтенсивність виділення ооцист, \% } \\
\hline & & & & МiH. & Серед. & Maкc. \\
\hline ПСП «Комишанське» & 98 & 71 & 72,6 & $4 / 2,3$ & $73 / 42,1$ & $87 / 42,8$ \\
\hline ТОВ «Беєве» & 17 & 2 & 12,4 & $2 / 1,1$ & $33 / 19,6$ & $38 / 29,6$ \\
\hline СТОВ «Ранок» & 64 & 25 & 38,7 & $3 / 1,9$ & $41 / 34,2$ & $57 / 39,7$ \\
\hline Загальний показник & 179 & 98 & 41,23 & $9 / 1,77$ & $147 / 31,96$ & $182 / 39,17$ \\
\hline
\end{tabular}

Клінічна картина при криптоспоридіозі телят була різною, в залежності від форми перебігу хвороби. Перші клінічні ознаки за нашими спостереженнями встановлювали вже з 3-4 дня від народження з максимальним проявом до 5-6 дня. Хворі телята мали різний ступінь пригніченості, шерстний покрив скуйовджений, забрудненість задньої частини тіла фекаліями, відсутність апетиту, виражена перистальтика кишечника. Спостерігали зміни рухової функції, залежування. Випорожнення тварин мали неприємний, гнилісний запах. Хворі тварини були виснаженими, жива вага різко знижувалась за рахунок дегідратації. При затяжному перебігу хвороби на п'яту добу реєстрували загибель тварин. При розтині 12 загиблих тварин, з скребків слизової оболонки клубової кишки виготовляли мікропрепарати, які досліджували мікроскопією в лабораторних умовах. Максимальний ступінь інвазії та різну стадію розвитку ооцист ми визначали із матеріалу отриманого від дев'яти голів загиблих телят. При патологоанатомічному розтині спостерігали яскраву, типову картину в шлунково-кишковому тракті. При огляді шлунково-кишкового тракту загиблих телят спостерігали катаральне запалення від сичуга, до прямої кишки. Вміст кишковика значно рідкий, запінений. Продовж кишечника слизова оболонка мала виражену гіперемію, набряк і велике нашаровування слизу. Слизова оболонка клубового відділу

Вісник Сумського національного аграрного університету 
кишковика вкрита багаточисельними крововиливами, в деяких ділянках з виразками. Мезентеріальні лімфовузли збільшені, насичені вологою, інтенсивно червоного кольору. Селезінка була без особливих змін. Печінкова капсула значно напружена.Відмічалася пряма залежність між яскравими патологоанатомічними змінами і ступенем ураженості кишковика криптоспоридіями. Значний набряк слизової оболонки тонкого відділу і клубової кишки був обумовлений інфільтрацією кров'яних тілець. Для підтвердження діагнозу патологічний матеріал направляли в лабораторію. Відібрана кров від хворих тварин досліджувалась в імунологічному відділі Сумської регіональної лабораторії Державної Служби України з питань безпечності харчових продуктів та захисту споживачів. В патоморфологічному відділі з матеріалу достовірно виявляли зміни слизової оболонки за рахунок накопичення криптоспоридій в ендогенній стадії розвитку. Пейєрові бляшанки гіперплазовані, просвіти крипт мали розширення з скупченістю розруйнованих клітин. Криптоспоридії, в ендогенній стадії розвитку ооцист, виявляли у ворсинках кишечника.

Аналізуючи показники гематологічних досліджень 3 матеріалу уражених телят криптоспоридіями реєстрували достовірне сповільнення швидкості осадження еритроцитів вже з 5 до 15 доби розвитку хвороби. Цей показник складав $0,3 \pm 0,1 \mathrm{mм/год.} \mathrm{Лейкоцитарний} \mathrm{профіль} \mathrm{змінювався} \mathrm{вже} \mathrm{на}$ першій добі розвитку збудника в організмі телям. На 15 добу реєструвалося зниження лейкоцитів від 5,5 + 0,61 до 4,4 + $0,42 \times 10 \%$ л. Вже 3 п'ятої доби визначається достовірне зниження гемоглобіну 93,0 \pm 136 г/л. Чисельність еритроцитів починає збільшуватися на десяту добу після захворювання до 6,5 \pm 0,96 × 1012/л. Починаючи з першого до 10 дня захворювання у лейкоцитарній формулі ми реєстрували базофіли, що свідчить про запальні процеси в організмі тварин. За біохімічними показниками сироватки крові хворих на криптоспоридіоз телят вже з першого дня захворювання визначали достовірне зменшення білка до найменших показників це 4,73 $\pm 0,96$ г.

Терапевтичні та профрілактичні заходи були спрямовані на застосуванні комплексу ефективних препаратів при криптоспоридіозі. Тварин відбирали в три групи, по вісім голів у кожній. Вікова категорія тварин з чотирьох до семиденного віку спонтанно захворівших. Враховувалась інтенсивність криптоспоридіозної інвазії. Телятам першої групи задавали Бровасептол в дозі 0,6 мл/10 кг маси тіла поєднуючи 3 фуракриліном відповідно до настанови щодо застосування. Бровасептол це однорідний порошок, світложовтого кольору з слабим специфічним запахом. Даний препарат вміщує сульфадиметоксин натрієву сіль, як діючу речовину та триметоприм. Препарат додатково комплекту- ється фрлаконами с розчином (хлорид натрію 0,9\%). Механізм дії сульфаніламідів і триметоприма базується на впливі до бактеріальної клітини, через фермантетивну її систему. Це порушує її ріст, розмноження та призводить до повної руйнації. Сполучення двох речовин направлено на антимікробну дії, а саме, на грампозитивні та грамнегативні бактерії, також, на ряд простіших Coccidia.

Тваринам другої групи ураженим ооцистами криптоспоридій задавали Бравітакокцид в дозі 1,5 г/10 кг маси тіла протягом десяти діб, з одночасним введенням вітаміну В1 внутрішньом'язево в дозі 1 мл на тварину один раз в день протягом п'яти діб. Бравітакокцид відноситься до водорозчинних препаратів, жовтуватого кольору. Виробником запропоновано, у дозі застосування, діючою речовиною $\epsilon$ гідрохлорид ампроліума, який має специфічну спрямованість на криптоспоридії виду C. parvus та C. muris. Окрім того, допоміжні речовини підвищують функціональну властивість епітелію кишковика та стійкість слизової до крововиливів, такими визначені Вітамін А і Вікасол. Вітаміни групи $B$, перш за все $B_{1}$ (тіамін) відноситься до нейротропним та використовується з лікувальною метою захворювань периферичної та центральної нервової системи. Дефіцит цих вітамінів в організмі може стати причиною розвитку нейропатій, тому рання діагностика і корекція не достатку вітамінів вказаної групи необхідна для запобігання незворотних неврологічних порушень.

Третя група телят слугувала як контрольна. Тваринам цієї групи вводили внутрішньом'язево по 2 мл 4 \% розчину Гентаміцину та по 100 мл $5 \%$ розчину глюкози. В зв'язку з тим, що криптоспоридіоз при середньо-важкому перебігу і важкому перебігу супроводжується функціональними порушеннями, ми застосовували комплексно препарати, в яких вище перечисленні препарати поєднувалися 3 стабілізуючими порушення обміну речовин. Окрім того, в склад комплексних препаратів були включені мікроелементи, комплекс вітамінів A, $€$ в профрілактичних дозах, які компенсують потребу в організмі телят в цих речовинах. Дані препарати використовували двічі в день. Курс лікуваня складав десять діб. Це надає можливість проаналізувати продовжену дію кокцидіастатиків та сповільнення ендогенної стадії розвитку збудника.

Інтенсивність інвазії, після застосування препаратів за такою схемою лікування, знижувалась в двічі. Результативність терапевтичних заходів визначали за ефективністю та збереженістю поголів'я при криптоспоридіозі. Встановлювали екстенсефективність за основними показниками: подовженості прояву клінічних ознак хвороби, гематогенному дослідженні, латентному періоду збудника (табл.3).

Таблиця 3.

Показники дії препаратів при криптоспоридіозі телят

\begin{tabular}{|c|c|c|c|c|c|c|}
\hline \multirow{3}{*}{ групи } & \multirow{3}{*}{ препарати } & \multicolumn{4}{|c|}{ Термін по подовженості, діб } & \multirow{3}{*}{$\mathrm{EE}, \%$} \\
\hline & & \multicolumn{2}{|c|}{ Клінічні симптоми } & \multicolumn{2}{|c|}{ Латентний період збудника } & \\
\hline & & Кількість діб & Середній показник & Кількість діб & Середній показник & \\
\hline 1 & Бровасептол в дозі 0,6 мл/10 кг маси тіла + фруракрилін & $1-6$ & 3,4 & $5-12$ & 7,2 & 51 \\
\hline 2 & Бравітакокцид в дозі 1,5 г/10 кг маси тіла + вітамін $\mathrm{B}_{1}$ & $1-3$ & 1,6 & $3-5$ & 4,3 & 84 \\
\hline 3 & Гентаміцин 4\% 2 мл +100 мл 5\% розчину глюкози & $2-7$ & 4,5 & $6-14$ & 12,1 & 32 \\
\hline
\end{tabular}

3 представленої таблиці видно, що найбільше високу ефективність при криптоспоридіозі телят за більшістю показниками було при використанні в комплексі бравітакокциду в дозі 1,5 г/10 кг маси тіла у сполученні з вітаміном групи $\mathrm{B}_{1}$.
Основний, клінічний синдром такий, як діарея припинявся вже на третю добу. Екстенсефективність цього препарату складала $84 \%$. Мінімальну екстенсефективність показав бровасептол в дозі 0,6 мл/10 кг маси тіла в комплексі 3 
фуракриліном до 51 \%. Аналізуючи показники по групі контролю, де застосовували $4 \%$ розчин гентаміцину в дозі 2 мл та $5 \%$ розчину глюкози цей показник складав $32 \%$ при критоспоридіозі телят. Гематологічним дослідженням було встановлено, що після курсу лікування у тварин першої групи гематокритна величина знижувалася до 43,7 + 0,57 \%, утримання еритроцитів до 7,1 \pm 0,19 × 1012/л, гемоглобіну до $10,39 \pm 0,23$ г/л в крові. Порівнюючи гематокритний показник у хворих тварин контрольної групи він складав 54,19 $\pm 0,85$ \%. Загальна кількість лейкоцитів в крові тварин, які підлягали лікуванню знаходилася на верхній межі фрізіологічної норми 12,01 $\pm 0,32 \times 109 / л$. В лейкоцитарній формулі відсоток паличкоядерних нейтрофрілів зменшувався до 5,18 \pm $0,16 \%$, але значно збільшилися сегментноядерні, цей показник відповідав 27,14 \pm 1,37 \%. Одночасно збільшувалась кількість моноцитів до $\overline{5,7} \pm 0,28 \%$.

Дослідження крові хворих тварин другої групи, мали екстенсефрективність застосованого препарату $84 \%$ при криптоспоридіозі телят та показало позитивні зміни до видужання. Кров таких тварин мала більш високе утримання гемоглобіну до 9,7 \pm 0,28 г/л, еритроцитів 5,89 \pm 0,21 х 1012/л, лейкоцитів до 10,42 \pm 0,5 x 109/л. Гематокритна величина знаходилася в межах до норми $37,5 \pm 0,54 \%$. Лейкограма цих тварин практично не відрізнялася від показників здорових тварин. Одним з показників затухання запального процесу в організмі встановлено зміни в кількості моноцитів, число яких уповільнено збільшувалося до 6,23 + 0,27 \%. При обґрунтуванні даних досліджень крові здорових і хворих тварин, які підпадали лікуванню, вже через двадцять діб після терапевтичних дій виявлялися деякі зміни. В крові телят, які оброблялися препаратами зберігались підвищені показники утримання гемоглобіну до 9,6 + 0,21 г/л, еритроцитів до 5,8 + 0,20 x 1012/л по відношенню показників здорових тварин, показники гемоглобіну в порівняні відповідали $9,2 \pm 0,42$ г/л, еритроцитів до 5,6 \pm 0,23 х 1012/л. Рівень лейкоцитів дорівнював показникам здорових тварин 9,4 $0,24 \times 109 /$ л.

Таким чином, можемо констатувати, що комплексна терапія має позитивний вплив на зниження летальності, зменшення репродукції ооцист, скороченню термінів клінічного прояву захворювання і більшому розвитку репаративних процесів.

1. Криптоспоридіоз телят має широке розповсюдження в господарствах Сумської та Чернігівської областях.

\section{Висновки.}

Екстенсивність інвазії у різних районах коливається від 12,4 $\%$ до 81,4 \% та в середньому складає 41,23 \% від обстеженого поголів'я. В різних територіально кліматичних зонах розташування господарств при обстеженні був майже однаковий рівень ураженості телят від 39,3 \% до 81,4 \%.

2. При обстежені хворих тварин був виявлений збудник Cryptosporidium parvus.

3. Термін ураженості та розвиток інвазії у новонароджених телят залежить прямо-пропорційно від їх утримання та сезонності. Починаючи вже з четвертої доби від народження реєструється виділення ооцист. Максимальна кількість спостерігається на сьому добу і показник складав 50,8 $\pm 0,47 \%$ в зимовий період та від 29,6 $\pm 0,25 \%$ до 42,8 $\pm 0,31$ \% в літню пору року.

4. При зараженні криптоспоридіями у телят спостерігається два піка екстенсивності інвазії. Перший реєструється на п'ятий день з початку виділення збудника. На сьому добу встановлюється друга хвиля виділення ооцист. Тривалість виділення ооцист Cryptosporidium у телят складає до 21 доби від народження.

5. Ветеринарно-санітарні умови утримання тварин відіграють значну роль у розповсюдженні збудника криптоспоридіозу серед сприйнятливого поголів'я. Накопичення ооцист у зовнішньому середовищі, обумовлює постійна його циркуляція у тваринницьких приміщеннях по утриманню новонароджених телят.

6. При гематологічному дослідженні встановлена екстенс-ефективність препаратів кокцидіостатиків при комплексному застосуванні. При їх використанні в крові тварин, які підлягали лікуванню, збільшується кількість гемоглобіну, еритроцитів. Рівень лейкоцитів та показники лейкограми відповідають фізіологічній нормі в процесі видужання.

Дослідження 3 даного питання свідчить про доцільність діагностики криптоспірозу в практичних умовах. При лабораторній діагностиці використовувати метод сегментації в розчині поверхнево-активних речовин, в модифікації. В якості засобів, які гальмують розвиток збудника, використовувати комплексно препарат вітчизняного виробництва Бравітакокцид в дозі 1,5 г/10 кг маси тіла з вітаміном $\mathrm{B}_{1}$ та поєднувати з препаратами, які стабілізують обмін речовин в організмі тварин. Сприяти підготовці приміщень з утримання новонароджених телят, з попереднім дослідженням в лабораторних умовах, змивів з стін, станків, предметів побуту, на забрудненість ооцистами збудника C. Parvum та інших представників інвазійних збудників.

\section{References:}

1. Bejer T.V., Antykova L.P., Herbyna H.Y. (2010). Obnaruzenye kryptosporydyoza čeloveka v Lenynhrade. [Detection of human cryptosporidiosis in Leningrad.] Medycynskaja parazytolohyja y parazytarnble bolezny. [Medical parasitology and parasitic diseases]. Ufa: Logos. № 2.45-47 [in Russian].

2. Bejer T.V., Sydorenko N.V., Hryhor'ev M.V. (1995). Cryptosporidium parvum. Apicomplexa: Sporosoa, Coccidia, optymyzacyja technykypolučenyja bol'šoj massы oocyst. [Cryptosporidium parvum. Apicomplexa: Sporosoa, Coccidia, optimization of the technique of obtaining a large mass of oocysts.]. Parazytolohyja. [Parasitology]. Ufa: Logos. № 3. 198-207 [in Russian].

3. Vasyl'eva V.A., Nebajkyna L.A. (1995). Kryptosporydyoz žyvotnыch. [Cryptosporidiosis of animals]. Veterynaryja. [Veterinary]. Kishinev: SKP. № 10. 31-32 [in Russian].

4. Grebenev A.L., Myagkova L.P. (2006). Bolezny kyšečnyka. [Intestinal diseases.] Covremennıle dostyženyja $v$ dyahnostyke y terapyy. [Modern advances in diagnosis and therapy]. M.: Medicine. 400 [in Russian].

5. Dahno I.S., Berezovsky A.V., Galat V.F. (2001). Atlas gel'mintiv tvarin. [Atlas of helminths of animals]. Kiïv: Vetinform. 34-59 [in Ukraine].

6. Zhurenko V.V. (2016). Vplyv zbudnyka kryptosporydiozu teljat na biochimični pokaznyky syrovatky krovi. [Influence of the causative agent of cryptosporidiosis of calves on serum biochemical parameters]. Naukovyj visnyk L'vivs'koho nacional'noho 
universytetu veterynarnoï medycyny ta biotechnolohiï imeni S.Z.Gžyc'koho. [Scientific Bulletin of SZ Gzhytsky Lviv National University of Veterinary Medicine and Biotechnology]. 18.3 (70). 100-102 [in Ukrainian]. DOI: http://dx.doi.org/10.31548/ujvs2019.01.051.

7. Zhurenko V.V., Soroka N.M., Zhurenko O.V. (2016). Porušennja fermentatyvnoï aktyvnosti u teljat,chvorych na kryptosporydioz. [Loss of enzymatic activity in calves, cryptosporidiosis ailments]. Problemy zooinženeriï ta veterynarnoï medycyny. [Problems of zooengineering and veterinary medicine]. No33. 135-137. [in Ukraine].

8. Zhurenko V.V. (2016). Porivnjal'na efektyvnist' metodiv diahnostyky kryptosporydiozu teljat. [Corresponding effectiveness of methods for diagnostics of cryptosporidosis in calves.] Naukovo-techničnyj bjuleten' Instytutu biolohiï tvaryn i Deržavnoho naukovo-doslidnoho kontrol'noho instytutu veterynarnych preparativ i kormovych dobavok. [Scientific and technical bulletin of the Institute of Biology of Tvarin and the State Scientific and Preliminary Control Institute of Veterinary Drugs and Feed Additives], 17.No 2. 135-137 [in Ukraine].

9. Krasnova O.P., Laryonov C.B., Rozovenko M.V. (2002). Dynamyka epyzootyčeskoho processa pry kryptosporydyoze teljat. Veterynaryja. [Veterinary]. Kishinev: SKP. № 4. 32-33 [in Russian].

10. Osypenko R.V., Maksyna T.P. (2012). Novyj sposob očystky y vydelenyja oocyst kryptosporydyj y druhych vydov kokcydyj yz byolohyčeskych substratov. [A new method for purification and isolation of oocysts of Cryptosporidium and other types of coccidia from biological substrates]. Aktual'nye problemy veterynarnoj medycyny [Actual problems of veterinary medicine], Ulyanovsk: Research Institute. № 2. 141-146 [in Russian].

11. Anusz K.Z., Mason P.H., Riggs M.W., Perryman L.E. (2002). Detection of Cryptosporidium parvum oocysts in bovine feces by monoclonal antibody capture enzyme-linked immunosorbent assay. Clin. Microbiol. 28.Vol.12. 770-774.

12. Bhat, S.A., Dixit, M., Juyal, P.D., Singh, N.K. (2014). Porivnjannja vkladenoï PLR ta mikroskopiï dlja vijavlennja kriptosporidiozu u teljat [Comparison of nested PCR and microscopy for the detection of cryptosporidiosis in bovine calves]. $\mathrm{J}$. Parasit. Dis. 38(1), 101-105. DOI: https://doi.org/10.1007/s12639-012-0201-5.

13. Casemore D.P. (1998). Laboratory methods for diagnosing cryptosporidiosis. Clin. Patol.44. № 6. 445-451.

14. Gnanasoorian S. (1998). Detection of Cryptosporidium oocysts in faecesi comparison of convential and immunofluorescense methods. Med. Lab. Sci. 49. №3. 21I-212.

15. Hall M.C. (2001). Some Laboratory Methods for Parasitological. Investigations Araer.J. of Hyg.Vol.8. 362-375.

Lidiia Kovalenko, Ph.D in Vet. Sciences, Sumy National Agrarian University, (Sumy, Ukraine)

Alexander Kovalenko, Ph.D in Vet. Sciences, Sumy Regional Laboratory of the State Service of Ukraine for Food Safety and Consumer Protection (Sumy, Ukraine)

Pathomorphological changes in the body of calves in protozoosis, prevention measures

The problem of establishing the prevalence of protozoa among animals is disclosed in this article. Cryptosporidiosis of calves is widespread in farms of Sumy and Chernihiv regions. The extent of infestation in different areas ranges from $12.4 \%$ to $81.4 \%$ and averages $41.23 \%$ of the surveyed livestock. In different territorial and climatic zones of the location of farms during the survey was almost the same level of involvement of calves from $39.3 \%$ to $81.4 \%$. Examination of sick animals revealed the pathogen Cryptosporidium parvus. The duration of infestation and the development of infestation in newborn calves depends in direct proportion to their content and seasonality. From the fourth day of birth, the allocation of oocysts is registered. The maximum number is observed on the seventh day and the figure was $50.8+0.47 \%$ in winter and from $29.6+0.25 \%$ to $42.8+0.31 \%$ in summer. two peaks of invasion extent. The first is registered on the fifth day after the onset of pathogen isolation. On the seventh day, the second wave of oocyst secretion is established. The duration of secretion of Cryptosporidium oocysts in calves is up to 21 days from birth. Veterinary conditions of animals play a significant role in the spread of cryptosporidiosis among susceptible livestock. The accumulation of oocysts in the environment is caused by its constant circulation in livestock facilities for keeping newborn calves. At hematological research the extension efficiency of drugs of coccidiostats at complex application is established. When they are used in the blood of animals to be treated, the amount of hemoglobin, erythrocytes increases. The level of leukocytes and leukogram parameters correspond to the physiological norm in the process of recovery. In laboratory diagnosis, a modified method of segmentation in a solution of surfactants was used. As a means of inhibiting the development of the pathogen, used a complex drug of domestic production Bravitacoccid at a dose of $1.5 \mathrm{~g} / 10 \mathrm{~kg}$ of body weight with vitamin B1 and combined with drugs that stabilize metabolism in animals .. Particular attention was paid to the preparation of premises for maintenance newborn calves, with a preliminary study in the laboratory, washed from the walls, machines, household items, oocyte contamination of the pathogen $\mathrm{C}$. Parvum and other representatives of invasive pathogens.

Key words: oocysts, biochemical analysis, hematological examinations, blood, feces, large intestine, mucous membrane, bravitacoccid, brovaseptol.

Дата надходження до редакції: 27.11.2020 р. 